\title{
Redbanded Hairstreak, Calycopis cecrops (Fabricius) (Insecta: Lepidoptera: Lycaenidae) ${ }^{1}$
}

\author{
Donald W. Hall and Jerry F. Butler ${ }^{2}$
}

\section{Introduction}

The redbanded hairstreak is a very attractive butterfly and is one of our most common hairstreaks throughout the southeastern United States in dry open woods and wooded neighborhoods.

\section{Distribution}

The redbanded hairstreak is found from Maryland to southeast Kansas to eastern Texas and throughout Florida. As a stray, it is occasionally found as far north as southern Wisconsin and Minnesota.

\section{Description}

The wingspread of the adult is 24 to $30 \mathrm{~mm}$. The under surface of the wings is gray-brown with a postmedial white line edged with a bright orange to red-orange band. Each hind wing has two tails (hairstreaks) with a relatively large conspicuous eyespot on the wing margin between the bases of the tails.

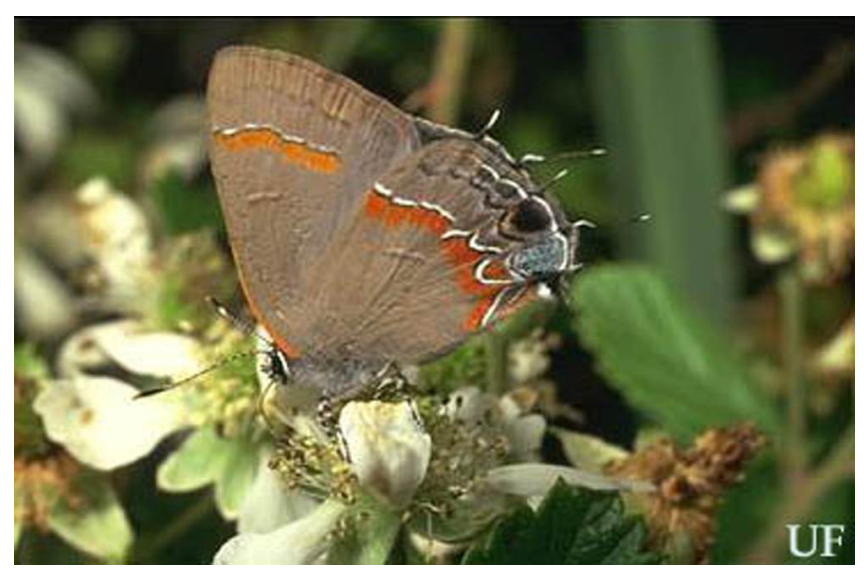

Figure 1. Adult redbanded hairstreak, Calycopis cecrops (Fabricius). Credits: Jerry F. Butler, University of Florida

Eggs are dimpled white turning to tan as hatching approaches. Larvae are brown with a median dorsal longitudinal stripe and covered with a coat of short hairs. Spiracles are conspicuous as dark submarginal spots on the prothorax and abdominal segments one through eight. Pupae are hairy and are light brown mottled with darker brown or black.

1. This document is EENY-108, one of a series of the Entomology and Nematology Department, Florida Cooperative Extension Service, Institute of Food and Agricultural Sciences, University of Florida. Original publication date August 1999. Reviewed May 2003. Visit the EDIS Web Site at http://edis.ifas.ufl.edu.

2. Donald W. Hall, professor and Jerry F. Butler, professor, Entomology and Nematology Department, Institute of Food and Agricultural Sciences, University of Florida, Gainesville, FL.

The Institute of Food and Agricultural Sciences (IFAS) is an Equal Opportunity Institution authorized to provide research, educational information and other services only to individuals and institutions that function with non-discrimination with respect to race, creed, color, religion, age, disability, sex, sexual orientation, marital status, national origin, political opinions or affiliations. U.S. Department of Agriculture, Cooperative Extension Service, University of Florida, IFAS, Florida A. \& M. University Cooperative Extension Program, and Boards of County Commissioners Cooperating. Larry Arrington, Dean 


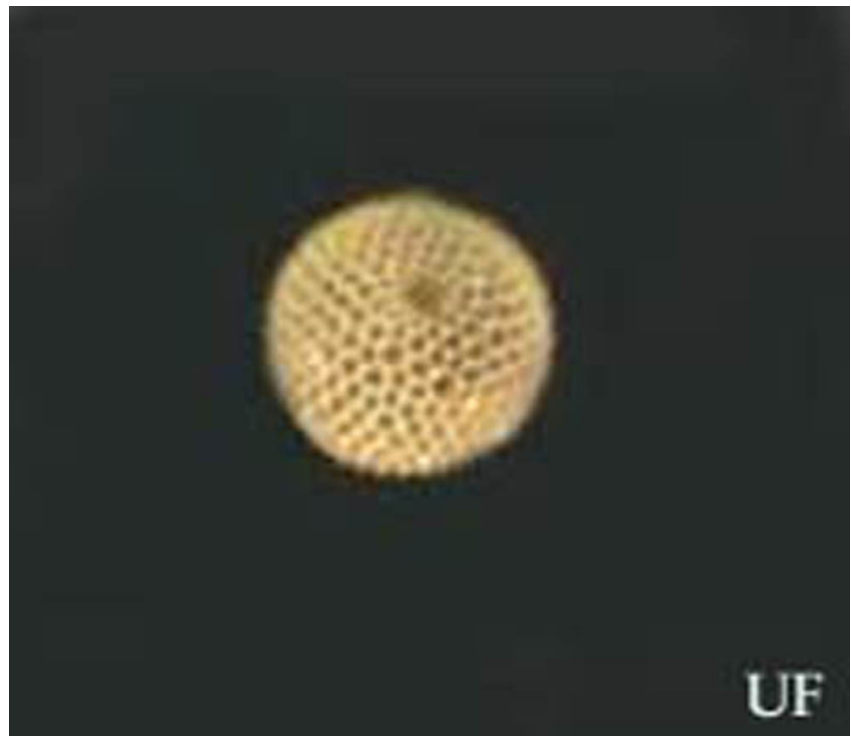

Figure 2. Egg of the redbanded hairstreak, Calycopis cecrops (Fabricius). Credits: Jerry F. Butler, University of Florida

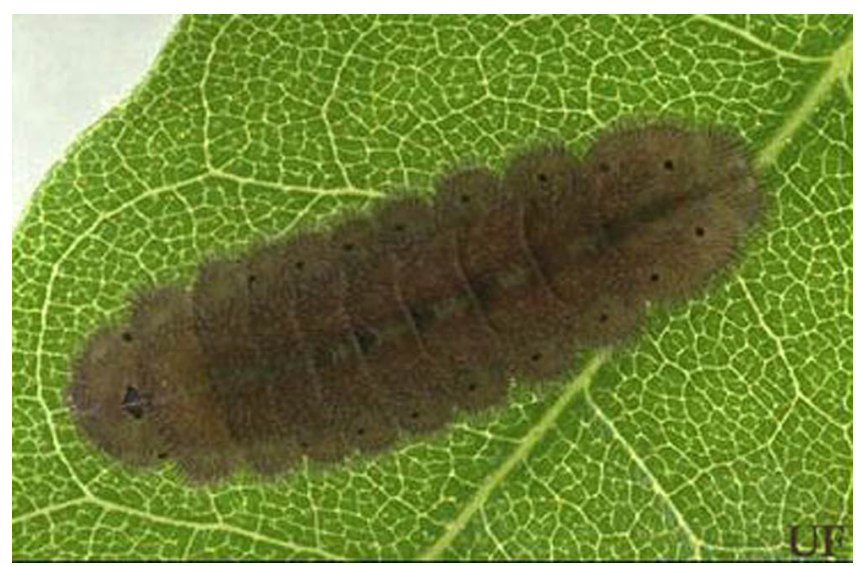

Figure 3. Larva of the redbanded hairstreak, Calycopis cecrops (Fabricius). Credits: Jerry F. Butler, University of Florida

\section{Life Cycle}

There are several flights (May-October) in the northern part of the range and year round in Florida. Adults feed on nectar and sip from mud. Males perch on vegetation to await the arrival of females for mating. As with the other hairstreak butterflies, perching adults move their hind wings up and down. The tails on the hind wings with their associated eyespots resemble a head. The movement of the tails is believed to attract a potential predator's attention to that part of the wings which then is torn away allowing the butterfly to escape.
Eggs are laid on the undersides of dead leaves on the ground beneath the host plants. Larvae are reported to feed on dead leaves and detritus in the leaf litter. However, at least in the laboratory, they will also feed on living foliage and flowers. Reported host plants include wax myrtle (Myrica cerifera L.) sumacs (particularly winged sumac, Rhus copallinum L.), crotons and oaks. Early fourth instar larvae overwinter.

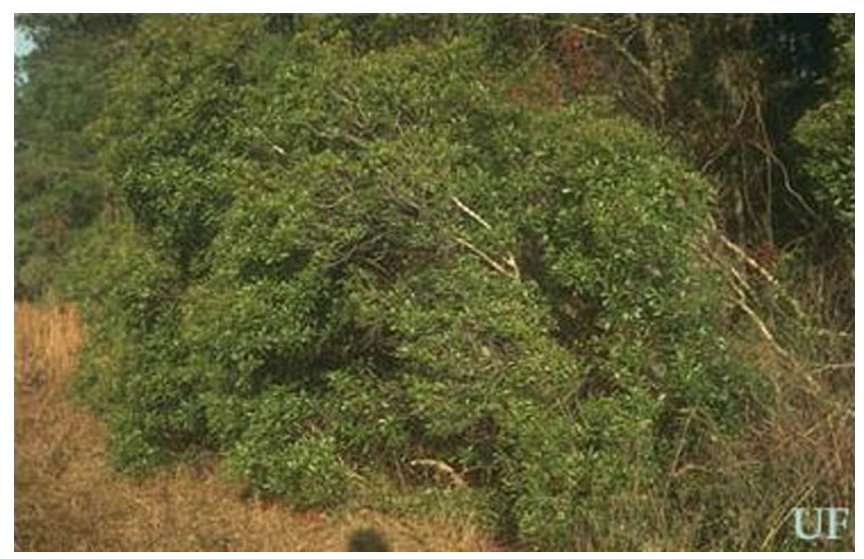

Figure 4. Wax myrtle, Myrica cerifera L. (Myricaceae). Credits: Donald W. Hall, University of Florida

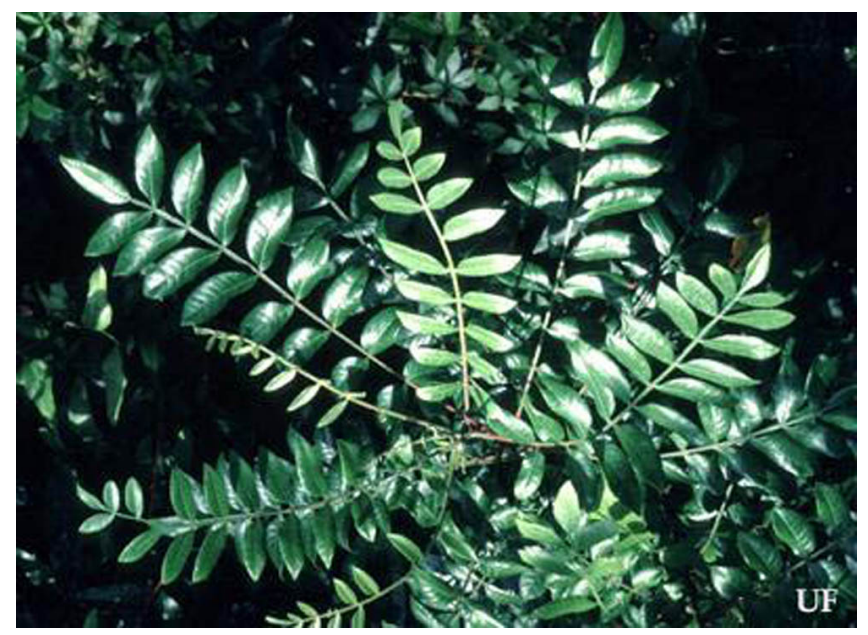

Figure 5. Winged sumac, Rhus copallinum L. (Anacardiaceae). Credits: Donald W. Hall, University of Florida

\section{Selected References}

Gerberg, E.J. and R.H. Arnett. 1989. Florida Butterflies. National Science Publications, Inc. Baltimore, MD.

Gifford, S.M. and P.A. Opler. 1983. Natural history of seven hairstreaks in coastal North Carolina. Journal of the Lepidopterists' Society. 37:97-105. 
Opler, P.A. and G.O. Krizek. 1984. Butterflies

East of the Great Plains. The Johns Hopkins

University Press. Baltimore, MD.

Opler, P.A. and V. Malikul. 1998. Eastern

Butterflies. Peterson Field Guide Series. Houghton

Mifflin Company. New York.

Scott, J.A. 1986. The Butterflies of North America. Stanford University Press. Stanford, CA. 